\title{
PENERAPAN LARANGAN PEMILIKAN \\ TANAH PERTANIAN SECARA ABSENTEE
}

\author{
Chandra Dewangga Marditya Putra \\ Advocat Anggota Peradi Kabupaten Malang \\ Jalan Kebonsari RT 12 RW 02 Ds. Ngebruk Kec Sumberpucung \\ Kab. Malang \\ Email: chandewa0808@ gmail.com
}

\begin{abstract}
Abstrak
Untuk menjadikan masyarakat tani yang adil dan makmur maka pemerintah melalui program landreform yang meliputi perombakan mengenai kepemilikan dan penguasaan tanah serta hubungan-hubungan hukum yang bersangkutan dengan penguasaan tanah. Sesuai dengan Pasal 10 ayat (1) Undang-Undang Pokok Agraria telah mengamanahkan terkait larangan kepemilikan atas tanah pertanian secara absentee. Dengan adanya ketentuan tersebut diharapkan para pemegang hak atas tanah pertanian dapat mengusahakan atau mengerjakan sendiri tanah yang dimilikinya sehingga tanah-tanah pertanian memang menjadi produktif dan tidak terdapat tanah pertanian yang di biarkan atau absentee. Tujuan larangan absentee agar hasil yang diperoleh dari pengusahaan tanah sebagian besar dapat dinikmati oleh masyarakat desa tempat letak tanah. Fenomena larangan tanah absentee/guntai secara nyata terjadi, tetapi tidak dilakukan sanksi yang tegas.
\end{abstract}

Kata kunci: absentee, kepemilikan hak atas tanah, pertanian, sanksi.

\section{Abstract}

To make a fair and prosperous farming community, the government through a Land Reform program which includes a reshuffle of land ownership and control as well as legal relations concerned with land tenure. In accordance with Article 10 paragraph (1) the Basic Agrarian Law mandates Absentee prohibitions on ownership of agricultural land. With the existence of these provisions it is expected that holders of agricultural land can cultivate or work on their own land so that agricultural lands are indeed productive and there is no agricultural land that is left or Absentee. The purpose of the Absentee ban is that the results obtained from the cultivation of land can be enjoyed mostly by rural communities where the land is located. The phenomenon of the prohibition 
of Absentee / guntai land actually occurred, but no strict sanctions were made.

Keywords: absentee,ownership of rights to land, agriculture, sanctions.

\section{PENDAHULUAN}

Untuk mewujudkan tujuan bangsa Indonesia adil makmur, maka Pemerintah telah membuat berbagai regulasi tentang pertanahan. Pada tanggal 24 September 1960 Pemerintah Indonesia telah mengundangkan Undang-Undang Nomor 5 Tahun 1960 Tentang Peraturan Dasar PokokPokok Agraria.Selanjutnya disebut sebagai UUPA.

UUPA telah mengamanatkan terkait larangan pemilikan atas tanah pertanian secara absentee. Sesuai dengan Pasal 10 ayat (1) UUPA yang menyebutkan bahwa "setiap orang dan badan hukum yang mempunyai sesuatu hak atas tanah pertanian pada asasnya diwajibkan mengerjakan atau mengusahakannya sendiri secara aktif dengan mencegah cara-cara pemerasan"

Dengan adanya ketentuan tersebut diharapkan para pemegang hak atas tanah pertanian dapat mengusahakan atau mengerjakan sendiri tanah yang dimilikinya sehingga tanah tanah pertanian memang menjadi produktif dan tidak terdapat tanah pertanian yang di biarkan atau absentee.

Untuk menjalankan peraturan dalam UUPA dan kebijakan landreform tersebut maka pada tanggal 19 September 1961 Pemerintah mengeluarkan Peraturan Pemerintah Republik Indonesia Nomor 224 Tahun 1961 tentang Pelaksanaan Pembagian Tanah dan Pemberian Ganti Kerugian yang telah ditambah dan disempurnakan melalui Peraturan Pemerintah Nomor 41 Tahun 1964. Peraturan tersebut merupakan pelaksanaan dari ketentuan dalam Pasal 10 ayat (1) UUPA dan Undang-Undang Nomor 56 Prp Tahun 1960 tentang Pembatasan Pemilikan Tanah Pertanian.

Ketentuan terkait menghapuskan tanah pertanian secara absentee telah diatur secara spesifik dalam Pasal 3 ayat (1) Peraturan Pemerintah Republik Indonesia Nomor 224 Tahun 1961 Tentang Pelaksanaan Pembagian Tanah dan Pemberian Ganti Kerugian yang menyebutkan bahwa pemilik tanah yang bertempat tinggal diluar kecamatan tempat letak tanahnya, dalam jangka waktu 6 bulan wajib mengalihkan hak atas tanahnya kepada orang lain di kecamatan tempat letak tanah itu atau pindah ke kecamatan letak tanah tersebut.

Ketentuan tersebut bertujuan melarang pemilikan tanah secara absentee supaya hasil pemilikan tanah itu sebagian besar dapat dinikmati oleh masyarakat pedesaan tempat letak tanah yang bersangkutan karena 
pemilik tanah akan bertempat tinggal di daerah tempat tanah pertanian tersebut berada. ${ }^{1}$

Pengecualian terhadap ketentuan tersebut terdapat dalam Pasal 3 ayat (2) PP 224 Tahun 1961 yang menyebutkan bahwakewajiban tersebut pada ayat (1) pasal ini tidak berlaku bagi pemilik tanah yang bertempat tinggal di kecamatan yang berbatasan dengan kecamatan tempat letak tanah, jika jarak antara tempat tinggal pemilik dan tanahnya masih memungkinkan mengerjakan tanah itu secara effisien, menurut pertimbangan panitia landreform Daerah Tingkat II.

Pengecualian yang kedua diperuntunkan bagi mereka, yang mempunyai tanah dikecamatan tempat tinggalnya atau dikecamatan sebagaiyang dimaksudkan dalam ayat 2 pasal PP 224 Tahun 1961, yang sedang menjalankan tugas Negara, menunaikan kewajiban agama, atau mempunyai alasan khusus lainnya yang dapat diterima oleh Menteri Agraria. Bagi pegawai-pegawai negeri dan pejabat-pejabat militer serta yang dipersamakan dengan mereka, yang sedang menjalankan tugas negara, perkecualian tersebut pada ayat ini terbatas pada pemilikan tanah pertanian sampai seluas $2 / 5$ dari luas maksimum yang ditentukan untuk daerah yang bersangkutan menurut Undang-undang Nomor 56 Prp Tahun 1960.

Apabila peraturan tersebut tidak dipatuhi maka pemilik atas tanah pertanian yang secara absente diancam dengan sanksi tanah yang bersangkutan diambil oleh Pemerintah, untuk kemudian dibagi-bagikan menurut ketentuan peraturan tersebut.

Semangat pembuatan regulasi oleh pemerintah Indonesia sebagaimana telah dipaparkan diatas masih terdapat kendala pada tataran implementasi di lapangan terkait larangan kepemilikan tanah secara Absentee. Salah satu daerah yang terdapat terdapat kepemilikan tanah pertanian secara Absentee adalah di Kabupaten Malang.

\section{METODE PENELITIAN}

Metode penelitian adalah prinsip-prinsip dan tata cara memecahkan suatu masalah. Sedangkan penelitian adalah pemeriksaan secara hati-hati tekun dan tuntas terhadap suatu gejala untuk menambah pengetahuan manusia, maka metode penelitian dapat diartikan sebagai prinsip tata cara untuk memecahkan masalah yang dihadapi dalam melakukan penelitian. ${ }^{2}$

Dalam penelitian ini jenis yang digunakan adalah penelitian yuridis empiris yang dengan kata lain adalah jenis penelitian hukum sosiologis dan dapat disebut pula dengan penelitian lapangan, yaitu mengkaji ketentuan

1 Boedi Harsono, Hukum Agraria Indonesia Sejarah Pembentukan UndangUndang Pokok Agraria, Isi dan Pelaksanaannya, (Jakarta:Jambatan, 2003), hal. 371

${ }^{2}$ Soerjono Soekamto, Pengantar Penelitian Hukum, (Jakarta:UI Press, 1986), hal.6. 
hukum yang berlaku serta apa yang terjadi dalam kenyataannya di masyarakat, ${ }^{3}$ atau dengan kata lain yaitu suatu penelitian yang dilakukan terhadap keadaan sebenarnya atau keadaan nyata yang terjadi di masyarakat dengan maksud untuk mengetahui dan menemukan fakta-fakta dan data yang dibutuhkan, setelah data yang dibutuhkan terkumpul kemudian menuju kepada identifikasi masalah yang pada akhirnya menuju pada penyelesaian masalah. Jenis penelitian ini dipilih agar dalam penelitian yang dilakukan bisa secara efektif menunjukkan antara bagaimana kenyataan dari permasalahan yang ada dengan bagaimana yang seharusnya menurut peraturan perundang-undangan. Sehingga antara kenyataan dengan aturan, sudah sesuai atau kah masih jauh dari kesesuaian diantara keduanya.

\section{PEMBAHASAN}

Kepemilikan dan penguasan tanah khususnya adalah pertanian yang dilakukan oleh para tuan tanah menjadi masalah tersendiri bagi tatanan kehidupan masyarakat. Pada umumnya tanah pertanian adalah semua tanah yang menjadi hak orang selain tanah untuk perumahan, bila atas sebidang tanah luas berdiri rumah tempat tinggal seseorang maka pendapat setempat itulah yang menentukannya, berapa luas bagian yang dianggap halaman rumah dan berapa yang merupakan tanah pertanian. ${ }^{4}$

Kepemilikan tanah pertanian oleh tuan tanah mengakibatkan kesenjangan sosial dalam masyarakat. Hal tersebut menjadikan masyarakat pedesaan khususnya adalah kaum tani masih hidup dalam keadaan yang jauh dari kata layak, padahal dalam Pasal 9 ayat (2) UUPA menyebutkan, bahwa tiap-tiap Warga Negara Indonesia, baik laki-laki maupun perempuan mempunyai kesempatan yang sama untuk memperoleh sesuatu hak atas tanah untuk mendapat manfaat dan hasilnya, baik bagi diri sendiri maupun keluarganya.

Masyarakat yang tinggal di pedesesaan yang bermata pencarian sebagai petani yang masih hidup jauh dari kata layak mau tidak mau harus menghadapi kenyataan kesenjangan sosial tersebut. Disatu sisi patani memerluhkan uang untuk melangsungkan kehidupan mereka, terkadang untuk mencukupi kebutuhan tersebut para petani harus menjual tanahnya kepada orang-orang yang kota yang bukan berprofesi sebagai petani.Dan disatu sisi petani juga takut kehilangan mata pencaharian mereka yang telah ditekuni selama ini. Sehinga dengan adanya keadaan tersebut banyak bermunculan petani-petani tanpa tanah. Mereka hanya melakukan

\footnotetext{
${ }^{3}$ Bambang Waluyo, Penelitian Hukum dalam Praktek, (Jakarta, Sinar Grafika,2002), hal,.15.

${ }^{4}$ Budhi harsono, Op. Cit. hal.358. 
penggarapan tanah pertanian milik orang lain atau biasa disebut petani gurem.

Keberadaan masalah sosial tersebut telah dilihat oleh pemerintah dengan mengeluarkan kebijakan landreform di Indonesia. Landreform berarti perubahan sistem kepemilikan dan penguasaan tanah yang melampaui diubah dengan sistem tata pertanahan baru yang disesuaikan dengan perubahan dan perkembangan masyarakat yang sedang giat melaksanakan pembangunan ekonominya.

Sejalan dengan hal tersebut UUPA telah meletakkan asas penghapusan tuan-tuan tanah besar.dalam Pasal 7 UUPA yang menetapkan bahwa untuk tidak mengurangi kepentingan umum, maka pemilikan dan penguasaan tanah yang melampaui batas tidak diperkenankan. Dengan adanya asas tersebut maka tanah memiliki fungsi sosial sehingga pemilikan tanah oleh pemilik tanah tidak hanya menimbulkan hubungan pribadi antara tanah dengan pemiliknya sehingga dalam UUPA juga mengatur mengenai Asas pembatasan luas maksimum dan/atau minimum tanah. Yang terdapat dalam Pasal 17 UUPA.

Untuk mewujudkan dan melaksanakan asas dalam Pasal 10 UUPA tersebut maka pemerintah melalui Peratuan Pemerintah Nomor 224 Tahun 1961 Tentang Pelaksanaan Pembagian Tanah dan Pemberian Ganti Kerugian telah menyebutkan secara khusus larangan kepemilikan tanah pertanian secara absentee. Dalam Pasal 3 PP 224 Tahun 1961 menyebutkan bahwa:

Ayat (1) Pemilik tanah yang bertempat tinggal diluar kecamatan tempat letak tanahnya, dalam jangka waktu 6 bulan wajib mengalihkan hak atas tanahnya kepada orang lain di kecamatan tempat letak tanah itu atau pindah ke kecamatan letak tanah tersebut.

Ayat (2)Kewajiban tersebut pada ayat 1 pasal ini tidak berlaku bagi pemilik tanah yang bertempat tinggal di kecamatan yang berbatasan dengan kecamatan tempat letak tanah, jika jarak antara tempat tinggal pemilik dan tanahnya masih memungkinkan mengerjakan tanah itu secara effisien, menurut pertimbangan Panitia Landreform Daerah Tingkat II

Ayat (3) Dengan tidak mengurangi ketentuan tersebut pada ayat 2 pasal ini, maka jika pemilik tanah berpindah tempat atau meninggalkan tempat kediamannya keluar kecamatan tempat letak tanah itu selama 2 tahun berturut-turut, ia wajib memindahkan hak miliktanahnya kepada orang lain yang bertempat tinggal di kecamatan itu.

Ayat (4) Ketentuan dalam ayat 1 dan 3 pasal ini tidak berlaku bagi mereka, yang mempunyai tanah dikecamatan tempat tinggalnya atau dikecamatan sebagai yang dimaksudkan dalam ayat 2 pasal ini, yang sedang menjalankan tugas Negara, menunaikan kewajiban agama, atau mempunyai 
alasan khusus lainnya yang dapat diterima oleh Menteri Agraria. Bagi pegawai-pegawai negeri dan pejabat-pejabat militer serta yang dipersamakan dengan mereka, yang sedang menjalankan tugas Negara, perkecualian tersebut pada ayat ini terbatas pada pemilikan tanah pertanian sampai seluas $2 / 5$ dari luas maksimum yang ditentukan untuk daerah yang bersangkutan menurut Undang-undang Nomor 56 Prp Tahun 1960.

Dalam pelaksanaan Peraturan Pemerintah Nomor 224 Tahun 1961 telah dianggap kurang sempurna, maka pemerintah melakukan Perubahan dan penambahanterhadap PP 224 Tahun 1961 Tentang Pelaksanaan Pembagian Tanah dan Pemeberian Ganti Kerugian yang tertuang dalam Peraturan Pemerintah Nomor 41 Tahun 1964 Tentang Perubahan Dan Tambahan Peraturan Pemerintah Nomor 224 Tahun 1961 Tentang Pelaksanaan Pembagian Tanah Dan Pemberian Ganti Kerugian. Dalam Pasal 3 PP 41 Tahun 1964 ditambahkan sebagai berikut:

Pasal 3a. Ayat (1) Pemilik tanah pertanian yang berpindah tempat atau meninggalkan tempat kediamannya keluar Kecamatan tempat letak tanah itu selama 2 (dua) tahun berturut-turut, sedang ia melaporkan kepada pejabat setempat yang berwenang, maka dalam waktu 1 (satu) tahun terhitung sejak berakhirnya jangka waktu 2 (dua) tahun tersebut di atas ia diwajibkan untuk memindahkan hak milik atas tanahnya kepada orang lain yang bertempat tinggal di Kecamatan letak tanah itu.

Ayat (2) Jika pemilik tanah yang dimaksudkan pada ayat (1) pasal ini berpindah tempat atau meninggalkan tempat kediamannya keluar Kecamatan tempat letak tanah itu, sedang ia tidak melaporkan kepada pejabat setempat yang berwenang, maka dalam waktu 2 (dua) tahun terhitung sejak ia meninggalkan tempat kediamannya itu diwajibkan untuk memindahkan hak milik atas tanahnya kepada orang lain yang bertempat tinggal di Kecamatan letak tanah itu.

Pasal 3b. Ayat (1) Pegawai Negeri dan Anggota Angkatan Bersenjata serta orang lain yang dipersamakan dengan mereka, yang telah berhenti dalam menjalankan tugas Negara dan yang mempunyai hak atas tanah pertanian di luar Kecamatan tempat tinggalnya dalam waktu 1 (satu) tahun terhitung sejak ia mengakhiri tugasnya tersebut diwajibkan pindah ke Kecamatan letak tanah itu atau memindahkan hak milik atas tanahnya kepada orang lain yang bertempat tinggal di Kecamatan di mana tanah itu terletak.

Ayat (2) Dalam hal-hal tertentu yang dapat dianggap mempunyai alasan yang wajar, jangka waktu tersebut dalam ayat (1) di atas dapat diperpanjang oleh Menteri Agraria.

Pasal 3c. (1) Jika seseorang memiliki hak atas tanah pertanian di luar Kecamatan di mana ia bertempat tinggal, yang diperolehnya dari warisan, 
maka dalam waktu 1 (satu) tahun terhitung sejak si pewaris meninggal diwajibkan untuk memindahkannya kepada orang lain yang bertempat tinggal di Kecamatan di mana tanah itu terletak atau pindah ke Kecamatan letak tanah itu.

Ayat (2) Dalam hal-hal tertentu yang dapat dianggap mempunyai alasan yang wajar jangka waktu tersebut dalam ayat (1) di atas dapat diperpanjang oleh Menteri Agraria.

Pasal 3d. Dilarang untuk melakukan semua bentuk pemindahan hak baru atas tanah pertanian yang mengakibatkan pemilik tanah yang bersangkutan memiliki bidang tanah di luar Kecamatan di mana ia bertempat tinggal.

Pasal 3e. Tidak dipenuhinya ketentuan-ketentuan tersebut dalam pasal- pasal 3a, 3b, 3c dan 3d mengakibatkan baik tanah maupun pemilik tanah yang bersangkutan dikenakan ketentuan-ketentuan tersebut dalam pasal 3 ayat (5) dan (6) Peraturan Pemerintah No. 224 tahun 1961 (Lembaran-Negara tahun 1961 No. 280).

Dengan adanya peraturan tersebut maka kepemilikan tanah pertanian secara Absentee pada prinsipnya tidak diperkenankan, karena dihawatirkan akan menumbuhkan tindakan pemerasan terhadap para petani seperti yang terjadi terhadap petani-petani pada masa penjajahan Belanda.

Menurut hasil penelitian di Desa Ngebruk sebagai salah satu Desa yang mayoritas mata pencariannya penduduknya sebagai Petani tidak terlepas dari kepemilikan tanah secara Absentee. Tanah-tanah pertanian sebagian dikuasai dan dimiliki secara Absentee oleh beberapa orang yang tinggal diluar daerah tanah tersebut. Pemilik tanah pertanian Absentee datang tidak hanya dari luar kecamatan akan tetapi pemilik tanah pertanian datang dari luar Kabupaten Malang bahkan ada yang dari luar Propinsi Jawa Tengah

Menurut Agus Riaji sekertaris Desa Ngebruk tanah pertanian yang dikuasai dan dimiliki secara Absentee di Desa Ngebruk terjadi karena peralihan hak berupa jual beli dan pewarisan. Pelaksanaan jual beli tanah khususnya tanah pertanian dilakukan dengan cara dibawah tangan antara penjual dan pembeli dihadapan Kepala Desa setempat dan disaksikan oleh para perangkat Desa Ngebruk. begitu pula dengan pewarisan biasanya para ahli waris datang ke Kantor Desa Ngebruk dan melakukan pembagian harta waris yang berupa tanah di hadapan kepala Desa dan disaksikan oleh perangkat Desa setempat ${ }^{5}$.

Tanah-tanah yang berada di Desa Ngebruk mayoritas alas haknya masih berbentuk Petuk pajak atau masyarakat setempat menyebutnya

${ }^{5}$ Agus Riaji, wawancara, selaku sekertaris Desa Ngebruk Kabupaten Malang pada tanggal 10 Januari 2019 
dengan "Tumpi". Keberadaan alas hak yang masih berbentuk petuk atau tumpi tersebut memudahkan para pembeli yang berkedudukan di luar desa Ngebruk untuk memiliki tanah pertanian. Menurut keterangan Sulistiani warga Desa Ngingit Kecamatan Tumpang Kabupaten Malang, pemilik tanah pertanian yang Absentee seluas $3800 \mathrm{M}^{2}$ di dusun Kebonsari RT 12 RW 02 Desa Ngebruk Kecamatan Sumberpucung Kabupaten Malang, ${ }^{6}$ peralihan tanah pertanian dilakukan dengan cara jual beli dibawah tangan hal tersebut dilakukan dengan alasan:

a. Peraliahan hak atas tanah pertanian dibawah tangan sudah menjadi kebiasaan masyarakat desa Ngebruk

b. Biaya peralihanya atas objek jual beli berupa tanah pertanian dengan cara dibawah tangan tergolong ringan

c. Prosesnya Cepat dan sederhana

Menurut keterangan Agus Riaji sekertaris Desa Ngebruk Jual beli tanah Pertanian yang dilakukan dibawah tangan dilakukan oleh Penjual dengan pihak pembeli yang masih memiliki hubungan keluarga atau setidaknya dikenal oleh masyarakat setempat, terkait dengan Kedudukan pembeli yang berada diluar wilayah tanah tersebut maka pemerintah Desa Ngebruk tidak melakukan pelarangan karena jual beli merupakan perbuatan yang pribadi atau privat, sehingga apabila terdapat perbuatan hukum jual beli tanah pertanian antara penjual dan pembeli tanah pertanian yang telah mendapatkan sepakat dengan harga tanah tersebut maka jual beli tanah pertanian dilakukan ${ }^{7}$.

Agus Riaji menambahkan berbeda dengan tanah pertanian yang telah memiliki sertipikat tanah, maka pihak Desa akan berkoordinasi dengan Kantor Pertanahan setempat dan pihak Pembeli tanah pertanian harus memiliki Kartu Tanda Penduduk dengan tempat tinggal di wilayah Desa Ngebruk meskipun nanti pembeli tersebut pindah lagi ke tempat domisili asal.

Keberadaan tanah absentee memang telah terjadi di Wilayah Kabupaten Malang, khusunya adalah yang belum bersertipikat, pihak Kantor Pertanahan sulit untuk melakukan pengawasan, akan tetapi kalau sudah bersertifikat Kantor Pertanahan Kabupaten Malang akan meneliti pengajuan permohonan peralihan hak yang diajukan khususnya dengan cara meneliti Kartu Tanda Penduduk yang bersangkutan.

Peralihan hak atas tanah tidak semunya didaftarkan di Badan Pertanahan Nasional atau Kantor Pertanahan sehingga dengan tidak

\footnotetext{
${ }^{6}$ Sulistiani, Wawancara, Pemilik Tanah pertanian Absentee di Desa Ngebruk Kabupaten Malang, Pada tanggal 10 Januari 2019.

${ }^{7}$ Agus Riaji, wawancara, selaku sekertaris Desa Ngebruk Kabupaten Malang pada tanggal 10 Januari 2019
} 
didaftarkannya peralihan hak atas tanah maka Pemerintah kesulitan dalam melaksanakan ketentuan landreform yang telah diamanahkan oleh peraturan perundang-undangan, kewenangan yang dimiliki oleh pemerintah untuk mengatur tentang pentang peralihan hak atas tanah salah satunya adalah ketentuan mengenai larangan kepemilikan tanah secara absentee. Dalam peralihan hak atas tanah pertanian dibawah tangan terkadang telah melanggar larangan kepemilikan tanah secara absentee.

Dengan demikian penerapan asas absentee tanah pertanian bagi pemegang hak atas tanah pertanian yang berkedudukan diluar wilayah apabila alashaknya masih berbentuk Petuk atau $\mathrm{C}$ desa atau tumpi maka penerapan asas absentee tersebut sulit diterapkan berbeda dengan tanah pertanian yang telah bersertipikat, penerapan asas absentee tanah pertanian bagi pemegang hak atas tanah pertanian tersebut Kantor Pertanahan Kabupaten Malang akan meneliti identitas yang berupa Kartu Tanda Penduduk yang bersangkutan apabila tidak tidak berkedudukan di mana tanah pertanian berada maka pengajuan peralihan hak akan ditolak, dan apabila telah sesuai dengan asas absentee maka akan diproses oleh kantor pertanan Kabupaten Malang.

Agus Riaji menjelaskan tanah tanah yang dimiliki secara absente memang dikerjakan oleh petani penggarap yang masih ada hubungan keluarga dengan pemilik tanah pertanian yang absente. ${ }^{8}$ Tanah-tanah absente yang dikelola dan dimanfaatkan oleh para petani penggarap dilakukan dengan sistem bagi hasil, akan tetapi sistem bagi hasil.

Boedi harsono menyatakan bahwa perjanjian bagi hasil hak usaha bagi hasil adalah hak seseorang atau badan hukum yang disebut penggarap untuk menyelenggarakan usaha pertanian diatas tanah kepunyaan pihak lain yang disebut pemilik dengan perjanjian bahwa hasilnya akan dibagi antara kedua belah pihak menurut imbalan yang telah disetujui sebelumnya. ${ }^{9}$

Menurut Undang-Undang nomor 2 Tahun 1960 yang dimaksud perjanjian bagi hasil adalah "perjanjian bagi hasil,ialah perjanjian dengan nama apapun juga yang diadakan antara pemilik pada satu pihak dan seseorang atau badan hukum pada lain pihak yang dalam undang-undang ini disebut"penggarap" berdasarkan perjanjian mana penggarap diperkenankan oleh pemilik tersebut untuk menyelenggarakan usaha pertanian di atas tanah pemilik, dengan pembagian hasilnya antara kedua belah pihak"

Dalam penelitian yang dilakukan oleh peneliti Perjanjian bagi hasil antara pemilik tanah dengan petani penggarap hanya dilakukan secara lisan, kapanpun pemililik tanah mau mengambil tanah pertanian miliknya maka

\footnotetext{
${ }^{8}$ Agus Riaji,Wawancara, Selaku Sekertaris Desa Ngebruk Kecamatan Klambu Kabupaten Malang, Pada Tanggal, 10 Januari 2019

${ }^{9}$ Boedhi Harsono, Op. Cit. hal.398.
} 
petani penggarap harus rela menyerahkan tanah garapannya tersebut kepada pemilik tanah. Pengelolaan dan pemanfaatan tanah pertanian semacam ini tidak efektif dan efisien dan tidak sesuai dengan asas Absentee yang bertujuan melindungi para petani.

Menurut Keterangan Nawawi pengelolaan dan pemanfaatan tanah pertanian pada saat ini masih kurang efektif efisien karena sebagai petani penggarap saya harus menyerahkan setengah hasil bersih dari panen kepada pemilik tanah. Petani penggarap juga harus menanggung biaya produksi seperti pupuk obat obatan dan biaya lain yang timbul atau biasa disebut biaya tanam. ${ }^{10}$

Beliau menambahkan bahwa pengelolaan dan pemanfaatan tanah pertanian akan efektif dan efisien apabila tanah pertanian memang benarbenar dimiliki dan dikerjakan oleh Para petani, Petani sebagai pemilik dan petani sebagai pengelola. Kalau dalam aturanya hanya menyebutkan harus orang yang tinggal di tempat sawah berada, tetapi sayangnya dalam aturan tersebut tidak mensyaratkan yang boleh memiliki tanah pertanian harus bekerja sebagai petani

Berdasarkan hasil penelitian yang dilakukan oleh peneliti, faktor yang menyebabkan terjadinya kepemilikan tanah secara Absentee di Kabupaten Malang adalah

\section{a. Faktor Subtansi}

Peraturan larangan pemilikan tanah pertanian secara absentee yang telah tertulis dalam Pasal 10 UUPA serta dalam Pasal 3 PP 224 Tahun 1961 yang sebagaimana disempurnakan dengan PP 41 Tahun 1964. Secara sosiologis adalah menjawab permasalahan konggrit yang terjadi di masyarakat pada tahun 1960 an.Adanya peraturan tersebut memang secara formil tidak ada masalah karena dikeluarkan sesuai dengan regulasi yang berlaku di Indonesia akan tetapi dari segi materi peraturan tersebut telah tidak sesuai dengan perkembangan yang ada pada masa sekarang.

Menurutut pendapat Van Kan yang menyatakan bahwa hukum selalu tertinggal dari perkembangan masyarakat, ${ }^{11}$ sehingga prodak hukum yang dikeluarkan akan selalu ketinggalan dengan perkembangan masyarakat yang sangat pesat.

Konsep pemikiran untuk membuat peraturan tentang larangan pemilikan tanah secara Absentee pada saat sekarang memang sudah tidak sesuai dengan keadaan zaman itu terlebih mengenai radius untuk kepemilikan tanah pertanian yang berbatasan kecamatan yang tidak lebih

\footnotetext{
${ }^{10}$ Nawawi, Wawancara, selaku Petani Penggarap tanah Absentee di Desa Ngebruk Pada tanggal 10 Januari 2019

${ }^{11}$ Romli Andasasmita, Analisis Ekonomi Mikro Tentang Hukum Pidana Indonesia edisi Pertama (Jakarta:Kencana,2016), hal. 10.
} 
dari $5 \mathrm{Km}$. dengan adanya kemajuan teknologi khususnya dalam bidang tranportasi maka jarak yang jauh tersebut dapat ditempuh dengan waktu yang singkat sehingga memang harus ada refisi terhadap peraturan tersebut .

Dengan demikian subtansi peraturan larangan kepemilikan tanah secara Absentee pada saat ini perlu dilakukan refisi yang disesuaikan dengan perkembangan masyarakat pada saat ini guna menjawab kebutuhan masyarakat tani pada saat ini.

\section{b. Faktor Penegak Hukum}

Untuk melihat bagaimana keefektifan peraturan larangan kepemilikan tanah secara Absentee dapat dilihat dari aparat penegak hukumnya. Apakah Penegak hukum yang telah diamahi untuk melaksanakan ketentuan tersebut menjalankan peraturan sebagaimana mestinya ataukah sebaliknya.

Dalam hal ini aparat penegak hukum larangan kepemilikan tanah pertanian secara absentee adalah Panitia Landreform tingkat II atau Kepala Kantor Pertanahan Kabupaten Malang.

Dalam hal telah terjadi peralihan hak atas tanah pertanian yang dimiliki secara absentee belum pernah melakukan penindakan hingga dibawa ke Pengadilan. Kantor pertanahan hanya melakukan penindakan dalam bidang adminidtrasi seperti tidak di lakukan pemprosesan jika terbukti pemohon peralihan hak telah melanggar asas absentee tanah pertanian.

Melihat dari hal tersebut faktor aparat penegak hukum sangat sentral dalam menegakkan asas absentee tanah pertanian. Penegak hukum adalah alat utama dalam penegakan hukum yang akan membawa berjalan atau tidak asas Absentee tanah pertanian.

\section{c. Faktor Kultur}

Mayarakat sebagai pihak yang terikat dalam berlakunya peraturan perundang-undangan menjadikan hal yang sentral dalam konsep efektifitas hukum.

dalam pelaksanaan peraturan larangan penguasaan dan pemilikan tanah secara absentee, ada kalanya masyarakat telah mengetahui larangan pemilikan tanah pertanian secara absentee, namun mereka sengaja melanggarnya untuk mewujudkan kepentingan pribadinya. Akan tetapi Kebanyakan dari mereka tidak mengetahui keberadaan peraturan tersebut.

Masyarakat yang mendapatkan tanah pertanian secara absentee terjadi karena jual beli. adanya hal tersebut menjadikan masyarakat disekitar wilayah tanah pertanian hanya sebagai petani penggarap. Hubungan hukum seperti ini telah umum terjadi dimasyarakat setempat, walaupun sebenarnya masyarakat khususnya para petani penggarap tidak mendapatkan hasil yang 
maksimal dalam pengelolaan dan pemanfaatan tanah pertanian yang telah melanggar asas absentee. ${ }^{12}$

Faktor budaya masyarakat yang menyebabkan kepemilikan tanah secara absentee adalah karena adanya pewarisan. Pewarisan ini terjadi karena adanya hubungan darah baik garis lurus ketas dan kebawah maupun menyamping serta karena adanya perkawinan atau adanya suatu wasiat yang harus dijalankan. Keberadaan ahli waris yang terkadang tidak berkedudukan di daerah objek harta waris yang berupa tanah pertanian menjadikan tanah pertanian tersebut menjadi tanah absentee. Karena sesuai dengan Pasal 3c. (1) PP 41 Tahun 1964 tentang Perubahan dan tambahan PP 224 Tahun 1961 Jika seseorang memiliki hak atas tanah pertanian di luar Kecamatan di mana ia bertempat tinggal, yang diperolehnya dari warisan, maka dalam waktu 1 (satu) tahun terhitung sejak si pewaris meninggal diwajibkan untuk memindahkannya kepada orang lain yang bertempat tinggal di Kecamatan di mana tanah itu terletak atau pindah ke Kecamatan letak tanah itu. Akan tetapi dalam budaya masyarakat setempat para ahli waris baru melakukan pemindahan hak lebih dari satu tahun.

Menurut Agus Riaji pelanggaran terhadap peraturan larangan kepemilikan tanah secara absentee diakibatkan karena adat masyarakat Desa Ngebruk yang baru melakukan pembagian harta waris setelah seribu hari dari kematian pewaris, selain hal tersebut anggapan bahwa menjual harta warisan adalah hal yang tabu karena masyarakat memiliki filosofi warisan itu "nak ora waris mesti gak krasan" artinya warisan itu kalau tidak waris ya tidak kerasan maksud dari filosofi tersebut adalah seorang pewaris harus bisa menjaga harta warisan dari ahli waris dan apabila tidak bisa menjaga harta waris tersebut pewaris akan selalu berupaya menjual dan dianggap gagal menjaga harta waris yang diperolehnya. Dengan kata lain bahwa menjual harta warisan dianggap hal yang tabu kecuali dalam keadaan yang terpaksa seperti untuk biaya berobat bagi anggota keluarga yang sedang sakit. ${ }^{13}$

Ketika ada peristiwa hukum berupa pewarisan terhadap harta waris yang berupa tanah pertanian, yang dimana ahli warisnya berada di perantauan selalu dianggap penduduk desanya. Dengan demikian secara materiil tanah pertanian yang dikuasai secara absentee memang ada akan tetapi secara formiil tidak terdeteksi sehingga tidak pernah diketahui datanya dan lolos dari ketentuan aturan kepemilikan tanah secara absentee yang menjadi salah satu objek landreform.

${ }^{12}$ Nawawi, Wawancara, Selaku Petani Penggarap di Desa Ngebruk Kecamatan Klambu Kabupaten Malang pada tanggal 10 Januari 2019.

${ }^{13}$ Agus Riaji,Wawancara, Selaku Sekertaris Desa Ngebruk Kecamatan Klambu Kabupaten Malang, Pada Tanggal, 10 Januari 2019. 
Dengan demikian kepemilikan tanah pertanian secara absentee akibat dari pewarisan tidak sesuai dengan keinginan mereka, karena waktu yang diberikan oleh Peraturan perundang-undangan sangat singkat yaitu hanya satu tahun yang dimana bertentangan dengan kebudayaan mereka yang baru membagi warisan setelah seribu hari dari meninggalnya si Pewaris.

\section{d. Faktor Sarana dan Prasarana}

Kepemilikan tanah pertanian secara absentee yang terjadi di masyarakat, salah satu faktor penyebab terjadinya kepemilikan tanah pertanian secara absentee diakibatkan karena belum ada sarana atau program yang terintegrasi antara sistem Kependudukan yang ada di Indonesia. Sistem yang digunakan pada saat ini masih manual hanya melihat pada Fotokopi pemohon peralihan hak atas tanah pertanian sehingga tidak bisa memastikan apakah identitas pemohon tersebut benar atau sebaliknya. ketika ada integrasi mungkin akan mencegah kepemilikan tanah pertanian secara absentee yang dilarang oleh undang-undang tersebut dapat dilaksanakan sehingga peraturan tersebut dapat dijalankan sebagaimana mestinya.

Dengan adanya Pasal tersebut Negara berharap bahwa yang menguasai dan memiliki tanah Pertanian adalah benar-benar petani produktif. Yang menghapus sejarah kelam para petani pada masa kolonialisme Belanda yang hanya dijadikan sapi perah dalam program cultur stelsel, Sehingga dengan mengeluarkan regulasi tersebut kehidupan para petani yang mayoritas hidup jauh dari kata layak dapat secara berangsur-angsung membaik dan dapat menjadi petani yang sejahtera.

sejalan dengan hal itu Pasal 11 ayat 1 dan 2 UUPA telah menyebutkan bahwa:

Ayat (1) Hubungan hukum antara orang, termasuk badan hukum, dengan bumi, air dan ruang angkasa serta wewenang-wewenang yang bersumber pada hubungan hukum itu akan diatur, agar tercapai tujuan yang disebut dalam pasal 2 ayat (3) dan dicegah penguasaan atas kehidupan dan pekerjaan orang lain yang melampaui batas.

Ayat (2) Perbedaan dalam keadaan masyarakat dan keperluan hukum golongan rakyat dimana perlu dan tidak bertentangan dengan kepentingan nasional diperhatikan dengan menjamin perlindungan terhadap kepentingan golongan yang ekonomis lemah.

Penegasan regulasi yang bertujuan untuk melindungi para petani dari monopoli tanah pertanian juga telah tersapat dalam Pasal 13 Ayat 2 UUPA yang menyebutkan bahwa Pemerintah mencegah adanya usaha-usaha dalam lapangan agraria dari organisasi-organisasi dan perseorangan yang bersifat monopoli swasta. Serta dalam PP 224 Tahun 1961 telah menyebutkan 
larangan pemilikan tanah secara absentee sebagai landasan dalam menyelenggarakan Indonesia sebagai negara hukum

Program yang dilakukan pemerintah dalam menangani peristiwa tersebut dengan mengeluarkan program landreform sebagai berikut:

1) Larangan untuk menguasai tanah pertanian yang melampaui batas

Ketentuan mengenai larangan untuk menguasai tanah pertanian yang melampaui batas telah diatur dalam Pasal 7 UUPA yang menyebutkan bahwa untuk tidak merugikan kepentingan umum maka pemilikan dan penguasaan tanah yang melampaui batas tidak diperkenankan. Maksud dari adanya ketentuan yang mengatur larangan pemilikan dan penguasaan tanah yang melampaui batas adalah agar tidak merugikan kepentingan umum sebab hubungan dengan terbatasnya persediaan tanah Khususnya daerahdaerah yang padat penduduknya, pemilikan dan penguasaan tanah yang melampaui batas itu akan menyebabkan kesempatan bagi pihak lain untuk dapat memiliki tanah sendiri menjadi sempit atau hilang sama sekali.

Tanah-tanah yang terkena ketentuan larangan pemilikan dan penguasaan tanah pertanian yang melampaui batas adalah tidak hanya tanah-tanah pertanina yang dipunyai dan dikuasai dengan hak milik melainkan seperti hak sewa, hak gadai, hak usaha bagi hasil.Tanah-tanah pertanian tersebut tidak hanya terletak pada satu daerah Kabuapten/Kota melainnkan dapat pula terpencar-pencar pada beberapa daerah kabupaten/kota.

Khusus untuk kepemilikan dan penguasaan tanah pertanian yang melampaui batas maksimum tetapi akibat karena adanya pewarisan tanpa wasiat diperbolehkan asal dalam jangka waktu satu tahun sejak perolehanya penerima warisan tersebut berusaha adar tanah pertanian yang dikuasainya itu tidak lagimelebihi batas maksimum

Pengecualian dari larangan kepemilikan dan penguasaan tanah pertanian yang melampaui batas maksimum adalah tanah tanahh yang dikuasai dengan hak Guna Usaha atau hak-hak lain yang bersifat sementara.

2) Larangan pemilikan tanah pertanian secara absentee

Secara implicit ketetuan pasal 10 UUPA menetapkan larangan pemilikan tanah pertanian secara absentee agar tanah pertanian dapat dikerjakan secara aktif oleh pemiliknya. Adapun yang dimaksud tanah absentee atau guntai adalah pemilikan tanah pertanian yang letaknya diluar kecamatan tempat tinggal pemilik tanah.

Semua bentuk pemindahan hak milik atas tanah pertanian melalui jual beli, tukar menukar, hibah yang mengakibatkan pemilikan baru tanah pertanian secara absentee/guntai dilarang. Tanah-tanah pertanian yang terkena larangan pemilikan tanah pertanian secara absentee/guntai akan 
dikuasai oleh pemerintah, untuk selanjutnya dijadikan objek landreform didistribusikan kepada petani yang memerluhan tanah dan kepada bekas pemilik tanah pertanian secara absentee/gutai akan diberikan ganri kerugian.

3) Redistribusi tanah yang selebihnya dari batas maksimum serta tanah-tanah yang terkena larangan Absentee, tanah bekas swapraja, dan tanah Negara lainnya

4) Pengaturan dan penebusan tanah tanah pertanian yang digadaikan.

Walaupun demikian, kepemilikan dan penguasaaan tanah pertanian secara Absentee masih saja terdapat Kabupaten Malang Khususnya di Desa Ngebruk. Hal ini menunjukkan bahwa implementasi terhadap aturan mendapatkan kendala-kendala dilapangan.

Menurut Agus Riaji kendala yang dihadapi dalam peneratapan asas absente ada beberapa faktor yaitu karena faktor ekonomi dan faktor budaya masyarakat. ${ }^{14}$

Menurut penelitian yang dilakukan peneliti kendala-kendala yang mempengaruhi tidak efektifnya larangan kepemilikan tanah pertanian secara Absentee adalah

a. Kurangnya kesadaran hukum masyarakat

Masyarakat yang lebih mengutamakan kepentingan pribadi untuk menguasai tanah pertanian dengan cara jual beli dibawah tangan serta tidak mendaftarkanya di Kantor pertanahan menyebabkan banyak terdapat tanah tanah yang dimiliki secara Absentee yang dimiliki oleh orang yang berkedudukan diluar wilayah

b. Budaya masyarakat

Yaitu karena adanya pewarisan yang masyarakat setempat tabu untuk melakukan peralihan hak atas objek harta waris yang berupa tanah pertanian yang Absentee

c. Faktor sarana dan prasarana

Yaitu belum adanya sarana tegnologi yang terintegrasi antara sistem kependudukan

d. Faktor aparat penegak hukum

Penegak hukum kurang aktif dalam melakukan penindakan terhadap pemilik tanah secara absentee

e. Faktor ekonomi

Yaitu masyarakat yang menganggap bahwa inversati yang paling aman adalah dengan membelikan tanah, yang nantinya bisa dinikmati ketika pemilik tersebut pensiun

\footnotetext{
${ }^{14}$ Agus Riaji,Wawancara, Selaku Sekertaris Desa Ngebruk Kecamatan Klambu Kabupaten Malang, Pada Tanggal, 10 Januari 2019
} 
f. Sanksi yang tidak berjalan

Yaitu para pemilik tanah absentee tidak dikenakan sanksi yang tegas sesuai dengan PP 224 Tahun 1961

Berdasarkan hal-hal diatas maka dalam penerapan asas Absentee tanah pertanian terdapat kendala kendala yaitu kesadaran hukum masyarakat budaya masyarakat sarana dan penegakan hukum sanksi yang kurang tegas sehingga penerapan asas Absentee tidak bisa diterapkan secara maksimal.

sanksi pidana juga telah tercantum dalam pasal 19 PP 224 tahun 1961 yang menyebutkan bahwa

Ayat 1 Pemilik tanah yang menolak atau dengan sengaja menghalang-halangi pengambilan tanah oleh Pemerintah dan pembagiannya, sebagai yang dimaksudkan dalam Pasal 2 ayat 2, dipidana dengan hukuman kurungan selama-lamanya 3 bulan dan/atau denda sebanyak-banyaknya Rp. 10.000,- sedang tanahnya diambil oleh Pemerintah tanpa pemberian ganti kerugian.

Ayat 2 Barang siapa dengan sengaja menghalang-halangi terlaksananya Peraturan Pemerintah ini dipidana dengan hukuman kurungan selama-lamaya 3 bulan dan/atau denda sebanyak-banyaknya Rp. 10.000,-

Hasil wawancara menyebutkan sanksi tersebut selama ini belum diterapkan, selama ini hanya menolak apabila terdapat pelanggaran terhadap larangan pemilikan tanah secara absentee.

Berdasarkan hal tersebut dalam prakteknya ketentuan sanksi terhadap pelanggaran asas absentee hanya bersifat administrasi dan belum pernah dilakukan penindakan yang sebuai dengan amah PP 224 tahun 1961.

Penegakan hukum terhadap larangan pemilikan tanah secara absentee merupakan usaha untuk mewujudkan ide-ide dan konsep-konsep hukum yang diharapakan rakyat menjadi kenyataan. Penegakan hukum merupakan suatu proses yang melibatkan banyak hal. Menurut Soerjono Soekanto, penegakan hukum adalah kegiatan menyerasikan hubungan nilainilai yang terjabarkan didalam kaidah-kaidah/pandangan nilai yang mantap dan mengejewantah dan sikap tindak sebagai rangkaian penjabaran nilai tahap akhir untuk menciptakan, memelihara dan mempertahankan kedamaian pergaulan hidup.

Penegakan hukum secara konkret adalah berlakunya hukum positif dalam praktik sebagaimana seharusnya patut dipatuhi. Oleh karena itu, memberikan keadilan dalam suatu perkara berarti memutuskan hukum in concreto dalam mempertahankan dan menjamin di taatinya hukum materiil dengan menggunakan cara procedural yang ditetapkan oleh hukum formal.

Berdasarkan hal diatas maka pengelolaan dan pemanfataan tanah pertanian yang efektif dan efisien sesuai dengan asas absentee dapat terjadi apabila pemilik dan pengelola memang benar-benar seorang petani yang 
tinggal di daerah dimana letak tanah pertanian itu berada karena seorang petatani memiliki keahlian dalam pengelolaan dan pemanfaatan tanah pertanian yang akan menimbulkan keefektifan dan efisiensi.

Dengan demikian penerapan asas absentee tanah pertanian bagi pemegang hak atas tanah pertanian yang berkedudukan di luar wilayah sebagaimana diatur dalam Pasal 3 PP 224 Tahun 1961 sebagaimana disempurnakan dengan PP 41 tahun 1964 masih belum di terapkan sesuai dengan peraturan tersebut. Hal ini dapat dikaji dengan teori efektifitas hukumyang dikemukakan oleh Lawren Fridmen atau Soejoyo Soekamto bahwa peraturan tersebut tidak efektif disebabkan karena subtansi aparat penegak hukum dan kultur masyrakat serta sarana dan prasanan yang kurang memadai.

Pengelolaan dan pemanfaatan tanah pertanian yang efektif dan efisien haruslah dilakukan oleh petani yang berkedudukan didaerah dimana letak tanah pertanian tersebut berada. Akan tetapi dalam PP 224 Tahun 1961 tidak pernah menyebutkan bahwa pemilik tanah pertanian adalah harus berprofesi sebagai petani.

Berdasarkan hal tersebut maka PP 224 Tahun 1961 harus dilakukan refisi dan penyempurnaan sehingga sesuai dengan kebutuhan masyarakat pada saat ini dan penerapan asas absentee tanah pertanian dapat dilaksanakan sebagaimana mestinya sehingga pengelolaan dan pemanfaatan tanah pertanian bisa efektif efisien sesuai dengan asas absentee yang menjadikan para petani sejahtera.

\section{KESIMPULAN}

Pererapan asas absentee tanah pertanian di Desa Ngebruk Kecamatan Sumberpucung Kabupaten Malang. Pemegang hak atas tanah pertanian apabila alas haknya masih berbentuk petuk atau Leter $\mathrm{C}$ maka penerapan asas absentee tidak dapat dilaksanakan karena para penjual dan pembeli melakukan jual beli tanah pertanian secara dibawah tangan dan kebanyakan tidak didaftarkan di Kantor Pertanahan Kabupaten Malang sehingga Kantor Pertanahan tidak dapat mendekteksi adanya peralihan hak tersebut dan apabila sudah berbentuk sertipikat tanah Kantor Pertanahan akan melakukan penelitian terhadap Identitas Pemohon peralihan hak kalau tidak sesuai dengan asas absentee maka kantor pertanahan Kabupaten Malang akan menolak permohon tersebut. Tanah pertanian yang absentee terjadi karena adanya jual beli dan pewarisan. Hal ini mengakibatkan penegakan peraturan dari Asas absentee tanah pertanian dalam prakteknya masih belum bisa ditegakkan, hal ini dikarenakan Subtansi hukum yang dianggap masih harus disempurnakan, penegakan hukum yang kurang tegas terhadap pelanggaran asas absentee, faktor budaya masyarakat yang 
menganggap menjual harta warisan yang berupa tanah pertanian dianggap tabu, serta sarana dan prasarana pendukung seperti Kartu Tanda Penduduk yang belum terintegrasi dengan sistem.

Penerapan asas absentee tanah pertanian mengalami hambatanhambatan dalam pelaksanaannya. Penghambat tersebut adalah masyarakat yang kurang sadar hukum dan menganggap bahwa tanah pertanian miliknya adalah hal yang mengandung unsur kepemilikan pribadi yang mutlak dan budaya masyarakat setempat yang menganggap bahwa harta warisan berupa tanah pertanian harus dijaga serta karena aparat penegak hukum yang kurang tegas dalam melakukan penerapan sanksi dan yang terahir karena faktor kebutuhan ekonomi.

Dalam sanksi yang diberikan ketika terdapat pemilik tanah pertanian yang melakukan pelanggaran terhadap asas absentee maka hanya menolak peralihan hak tersebut.

\section{DAFTAR PUSTAKA}

Bambang Waluyo, 2002, Penelitian Hukum dalam Praktek, Jakarta, Sinar Grafika.

Boedi Harsono, Hukum 2003, Agraria Indonesia Sejarah Pembentukan

Undang-Undang Pokok Agraria, Isi dan Pelaksanaannya, Jakarta:Jambatan, 2003.

Soerjono Soekamto, 1986, Pengantar Penelitian Hukum, Jakarta:UI Press.

Romli Andasasmita, 2016, Analisis Ekonomi Mikro Tentang Hukum Pidana Indonesia edisi Pertama Jakarta: Kencana. 